\title{
OXIDATIVE STRESS REDUCING AND LIVER PROTECTIVE EFFICACY OF ETHYL ACETATE FRACTION ISOLATED FROM PAJANELIA LONGIFOLIA (WILLD) K. SCHUMAN
}

\author{
SUPARNA DATTA*, MANABENDRA DUTTA CHOUDHURY \\ Ethnobotany and Medicinal plants Research Laboratory, Department of Life Science and Bioinformatics, Assam University, Silchar, Assam, \\ India. Email: bd.suparna@gmail.com
}

Received: 02 January 2017, Revised and Accepted: 09 March 2017

\section{ABSTRACT}

Objectives: We investigated the liver protective as well as oxidative stress reducing activity of isolated fractions (Pajanelia fraction-1, 2, and 3 [PF1, PF2, and [PF3]) from ethyl acetate extract of Indian medicinal plant Pajanelia longifolia (Willd.) K. Schuman.

Methods: The liver protective activity of fractions was evaluated against carbon tetrachloride ( $\left.\mathrm{CCl}_{4}\right)(0.5 \mathrm{ml} / \mathrm{kg}$ body weight intraperitoneal [b.w. i.p.]) induced hepatic damage in Swiss albino mice. Isolated fractions (at dose level of $150 \mathrm{mg} / \mathrm{kg}$ b.w. per orally [p.o.]) were administered to mice before 30 minutes of $\mathrm{CCl}_{4}$ administration. Silymarin at a dose of $50 \mathrm{mg} / \mathrm{kg}$ b.w. p.o. was taken as a standard drug. The liver protective activity of fractions was measured on serum biochemical parameters such as serum glutamic pyruvic transaminase, serum glutamic oxaloacetic transaminase, serum alkaline phosphatase, and bilirubin (total). Further antioxidant activity of fractions was also measured on antioxidant enzymatic and non-enzymatic levels such as reduced glutathione, lipid peroxidation, superoxide dismutase, catalase, and glutathione peroxidase.

Results: The in vivo study revealed that the PF3 most effectively protected the liver from damage by $\mathrm{CCl}_{4}$. The findings were also confirmed by histopathological observations. High-performance liquid chromatography result was clearly indicated that the fraction was pure.

Conclution: Ethyl acetate fraction (Pajanelia fraction 3) from P. longifolia may be considered as a liver protective agent.

Keywords: Liver protective activity, Biochemical parameters, High-performance liquid chromatography study, Histopathological observations, Pajanelia longifolia (Willd.) K. Schuman.

(C) 2017 The Authors. Published by Innovare Academic Sciences Pvt Ltd. This is an open access article under the CC BY license (http://creativecommons. org/licenses/by/4. 0/) DOI: http://dx.doi.org/10.22159/ajpcr.2017.v10i6.16898

\section{INTRODUCTION}

Reactive oxygen species (ROS) plays a significant role in regulation of cell growth, energy production and intercellular signaling and over production of ROS results in loss of detoxification capacity of the body cell which causes extensive damage to DNA, protein, carbohydrate, and lipids $[1,2]$.

ROS are inevitably generated due to the incomplete reduction of $\mathrm{O}_{2}$ in electron transfer reactions as byproducts of biological reactions. Antioxidants, the substances which have the capacity to eliminate the pro-oxidants and scavenge free radicals play a protective role against cell damage caused by oxidative stress. Natural antioxidants isolated from plant material have an excellent protective efficacy against such damages $[3,4]$. Numerous medicinal plants and their crude extracts have been reported for their hepatoprotetive and antioxidant activity [5]; very insignificant number of drugs have come out from all those works till date. Silymarin, a plant-based hepatoprotective drug isolated from Silybum marianum (L.) got major attention for its curative efficacy and become both scientifically and commercially acclaimed. However, this drug is not adequate in all respect to give oxidative stress release. On the other hand, synthetic drugs cause severe side effects. It has found in several studies that plant derived antioxidants scavenge free radicals. The study of free radical scavenging activity and the chemistry of free radical is complicated. Therefore, it necessitates the search for alternative potent herbal drugs to combat these deficiencies. Hence, it is always necessary to find suitable curative agents for the treatment of liver disease as well as oxidative stress release from natural plants products [6-9].

Pajanelia longifolia (Willd.) K. Schuman, belongs to the family Bignoniaceae, is traditionally known to be a very effective hepatoprotective agent and used in ailments for curing jaundice in Southern Assam. Therefore, the aim of our study was to search a suitable, less cytotoxic and efficient lead molecule for liver diseases. P. longifolia (Willd.) K. Schuman, found in Southern Assam, is traditionally known to be a very effective hepatoprotective agent and it is used in folklore medicine for curing jaundice. Therefore, this plant has been chosen for the experimental investigation whether its bark has any antioxidant efficacy or not. However, from literature survey, it was found that there are few reported scientific studies that have been carried out regarding the hepatoprotective activity of the plant [10]. Therefore, it was our interest to investigate the oxidative stress reducing and liver protective efficacy of the isolated fractions from ethyl acetate extract of stem bark of this plant against carbon tetrachloride $\left(\mathrm{CCl}_{4}\right)$ induced hepatic damage in Swiss albino mice.

\section{METHODS}

\section{Plant material}

P. longifolia (Willd.) K. Schuman was collected from Cachar District of Southern Assam part of Northeast India. The plant was identified at the Assam University Herbarium, Silchar, and a voucher specimen (H-17) was deposited for future reference. The air-dried and powdered bark ( $500 \mathrm{~g}$ ) was defatted at room temperature with n-hexane followed by extraction with ethanol $(1500 \mathrm{ml})$. Qualitative phytochemical screening of the crude extracts was performed following the method [11].

Thin layer chromatography (TLC) analysis and column chromatography of crude extract

The sample was dissolved in minimum amount of solvent and absorbed on silica gel (60-120 mesh) and allowed to dry. The column was eluted with n-hexane, and then the polarity was gradually increased using ethyl acetate and acetone. Eluents were collected in $500 \mathrm{~mL}$ reagent bottle 
(Qualigens), and the progress of the separation was monitored by thin layer chromatography, using the solvent system hexane, ethyl acetate (9:1, 9.5:0.5, 8.5:1.5, and 4:1) and hexane, ethyl acetate, methanol (9:0.5:0.5, 8:1:1, and 7.5:2:0.5) a total of 38 fractions were collected. Fraction $(10,16$ and 21) after preparative thin layer chromatography gave a single spot on TLC using different solvent system with different ratios.

\section{Purity of fractions}

The percentage of purity of fractions were checked by analytical high-performance liquid chromatography (HPLC) (Perkin Elmer, S-200, Volume: $1.000000 \mathrm{ul}$, Sample Amount: 1.0000, Channel: A, A/D mV Range: 1000, End Sampling Rate: 10.0000 pts/s, Sample Time: 20.00 min, Area Reject: 0.000000, Dilution Factor: 1.00, Cycle: 1).

\section{Methodology for bioactivity analysis}

Animal

Swiss albino mice (24-26 g) of either sex were used as animal model. The animals were maintained under controlled conditions throughout the period of experiment. They were provided with standard laboratory diet. Ethical committee approval was sorted before the experiment.

\section{Chemicals}

All chemicals were of analytical grade and purchased from Merck India Ltd., Mumbai, India. Silymarin received from Ranbaxy India Ltd. as gift sample.

\section{$\mathrm{CCl}_{4}$ induced hepatotoxicity}

The hepatic injury was induced using $\mathrm{CCl}_{4}[12]$ with slight modifications. On the basis of acute toxicity study, the dose concentration of $150 \mathrm{mg} / \mathrm{kg}$ body weight per orally (b.w. p.o.) (F1, F2 and F3) was selected. Animals were divided into six groups with six animals each as follows, Group I: Normal control, received liquid paraffin ( $1 \mathrm{ml} / \mathrm{kg}$ b.w. p.o.) for 5 days. Group II: Negative control, treated with $\mathrm{CCl}_{4}(0.5 \mathrm{ml} / \mathrm{kg}$ b.w. p.o.) for 5 days. Group III: Positive control treated with silymarin ( $50 \mathrm{mg} / \mathrm{kg}$ b.w. p.o.) and then after 30 minutes, $0.5 \mathrm{ml} / \mathrm{kg}$ b.w. of $\mathrm{CCl}_{4}$ intoxicated intraperitoneally for 5 days. Group IV, $\mathrm{V}$ and VI treated with (F1, F2 and F3 150mg/kg b.w. p.o, respectively, and then after 30 minutes, $0.5 \mathrm{ml} / \mathrm{kg}$ b.w. of $\mathrm{CCl}_{4}$ intoxicated intraperitoneally for 5 days. On the $6^{\text {th }}$ day, the animals were sacrificed to assess the liver function and histological changes.

\section{Biochemical assay}

Serum of Swiss albino mice was used for biochemical analysis, such as serum glutamic oxaloacetic transaminase (SGOT) and serum glutamic pyruvic transaminase (SGPT) [13]. The bilirubin content [14] and the serum alkaline phosphatase (SALP) [15].

\section{Preparation of liver homogenate}

The liver homogenate was prepared as per the method [16].

Measurement of antioxidant enzymatic and nonenzymatic levels Measurement of antioxidant enzymatic and non-enzymatic levels was done according to standard procedures. Catalase (CAT) [17], superoxide dismutase (SOD) [18], glutathione peroxidase (GPx) [17], reduced glutathione (GSH) [19], and lipid peroxidation (LPO) [20].

\section{Histopathological observation}

Liver tissues were fixed in $10 \%$ formalin and were graded with ethanol. The paraffin embedded liver tissue were cut into thin sections, stained with hematoxylin-eosin dye and observed under microscope (BX41, OLYMPUS) to note the changes in the liver tissue.

\section{Statistical analysis}

The data presented here were expressed as mean \pm stnadard error. The results were analyzed by one way ANOVA with Tukey-Kramer multiple comparisons test. The level of significance was accepted at $p<0.001$, $\mathrm{p}<0.01$ and $\mathrm{p}<0.05$.

\section{RESULTS}

\section{Preliminary phytochemical screening}

The preliminary phytochemical screening of ethyl acetate extract revealed the presence of secondary metabolites such as alkaloids, steroids, tannin, reducing sugar, and flavonoids.

\section{Column chromatography of the extract}

Column chromatography was carried out with ethyl acetate bark extract in a usual manner using solvents on the basis of their polarity and after collecting appropriate fractions the preparative TLC was done. Fractions $(10,13,16,19,21,28$ and 32) were subjected to preparative TLC with different solvent systems to check the purity of fractions. Preparative TLC of fractions10 (Pajanelia fraction-1 [PF1]), fraction 16 (PF2) and fraction 21 (PF3) with different solvent systems exhibited one spot.

\section{Purity of fraction}

From analytical HPLC study of PF3 exhibited single spot in TLC which is existing in farely pure form (Fig. 1)

\section{Bioactivity analysis \\ Biochemical assay}

Mice treated with a single dose of $\mathrm{CCl}_{4}$ developed significant $(\mathrm{p}<0.001$, control vs. toxic group) hepatic damage as observed from elevated levels of SGOT (81.17 \pm 2.18$)$, SGPT $(94.74 \pm 1.31)$, SALP (134.25 \pm 2.19$)$, and serum bilirubin $(3.82 \pm 0.02)$. Treatment with $150 \mathrm{mg} / \mathrm{kg}$ b.w. p.o. dose of fraction PF1, PF2 and PF3 exhibited significant $(\mathrm{p}<0.001$ compared to toxic group and $\mathrm{p}<0.001, \mathrm{p}<0.01$ and $\mathrm{p}<0.05$ compared to control group) liver protective activity in serum enzyme and bilirubin levels of Swiss albino mice. Fraction PF3 exhibited maximum level of (significant at $\mathrm{p}<0.001$ compared to toxic group) liver protective effect in SGOT (29.22 \pm 1.97$)$, SGPT $(24.72 \pm 2.89)$, SALP $(61.79 \pm 2.11)$ and serum bilirubin $(0.52 \pm 0.01)$ compared to the other two fractions (PF1 and PF2). The protective efficacy of fraction PF3 was high compared to that of protective efficacy exhibited by standard drug silymarin (Table 1). The results were also supported by histopathological observations.

Measurement of antioxidant enzymatic and nonenzymatic levels Single dose of $\mathrm{CCl}_{4}$ developed significant damage in hepatic cells of Swiss albino mice as observed from elevated levels of LPO $(5.19 \pm 0.03)$ and decreased levels of SOD $(0.72 \pm 0.01$ unit/mg protein $)$, CAT

Table 1: Protective effect of isolated fractions on serum biochemical parameters against $\mathrm{CCl}_{4}$ induced hepatotoxicity in Swiss albino mice

\begin{tabular}{lllll}
\hline Doses & $\begin{array}{l}\text { SGOT } \\
\text { (IU/L) }\end{array}$ & $\begin{array}{l}\text { SGPT } \\
\text { (IU/L) }\end{array}$ & $\begin{array}{l}\text { SALP } \\
\text { (IU/L) }\end{array}$ & $\begin{array}{l}\text { Bilirubin } \\
\text { (IU/L) }\end{array}$ \\
\hline Group I & $26.61 \pm 1.55$ & $18.85 \pm 2.05$ & $41.67 \pm 2.11$ & $0.31 \pm 0.01$ \\
Group II & $81.17 \pm 2.18^{\mathrm{a}}$ & $94.74 \pm 1.31^{\mathrm{a}}$ & $134.25 \pm 2.19^{\mathrm{a}}$ & $3.82 \pm 0.02^{\mathrm{a}}$ \\
Group III & $43.09 \pm 1.62^{\mathrm{e}}$ & $24.08 \pm 1.12^{\mathrm{e}}$ & $81.79 \pm 0.85^{\mathrm{b}, \mathrm{e}}$ & $0.74 \pm 0.01^{\mathrm{a}, \mathrm{e}}$ \\
Group IV & $74.18 \pm 0.69^{\mathrm{e}}$ & $61.54 \pm 1.27^{\mathrm{e}}$ & $72.17 \pm 0.77^{\mathrm{b}, \mathrm{e}}$ & $1.03 \pm 0.03^{\mathrm{a}, \mathrm{e}}$ \\
Group V & $54.72 \pm 3.01^{\mathrm{c}, \mathrm{e}}$ & $37.19 \pm 1.55^{\mathrm{e}}$ & $63.16 \pm 1.10^{\mathrm{a}, \mathrm{e}}$ & $1.16 \pm 1.10^{\mathrm{a}, \mathrm{e}}$ \\
Group VI & $29.22 \pm 1.97^{\mathrm{a}, \mathrm{e}}$ & $24.72 \pm 2.89^{\mathrm{b}, \mathrm{e}}$ & $61.72 \pm 2.89^{\mathrm{b}, \mathrm{e}}$ & $0.52 \pm 2.11^{\mathrm{a}, \mathrm{e}}$ \\
\hline
\end{tabular}

$\mathrm{n}=6$ animal, values are given as mean $\pm \mathrm{SE}$, values are statistically significant at $\mathrm{p}<0.001, \mathrm{p}<0.01$ and $\mathrm{p}<0.05$ level of significance. ${ }^{\mathrm{a} C o m p a r e d}$ with control $\mathrm{p}<0.001,{ }^{\mathrm{b}} \mathrm{Compared}$ with control $\mathrm{p}<0.01,{ }^{\mathrm{c}} \mathrm{Compared}$ with control $\mathrm{p}<0.05$, ${ }^{\mathrm{d}}$ Compared with standard $\mathrm{p}<0.001$, ${ }^{\mathrm{e}}$ Compared with toxic $\mathrm{p}<0.001$. Group I - Control, Group II - Toxic ( $\left.\mathrm{CCl}_{4}\right)$, Group III - Standard (Silymarin), Group IV - 150 mg/kg b.w. p.o. dose of PF1; Group V - 150 mg/kg b.w. p.o. dose of PF2; Group VI - $150 \mathrm{mg} / \mathrm{kg}$ b.w. p.o. dose of PF3. SGOT: Serum glutamic oxaloacetic transaminase, SGPT: Serum glutamic pyruvic transaminase, SALP: Serum alkaline phosphatase, SE: Standard error, $\mathrm{CCl}_{4}$ : Carbon tetrachloride, PF: Pajanelia fraction 


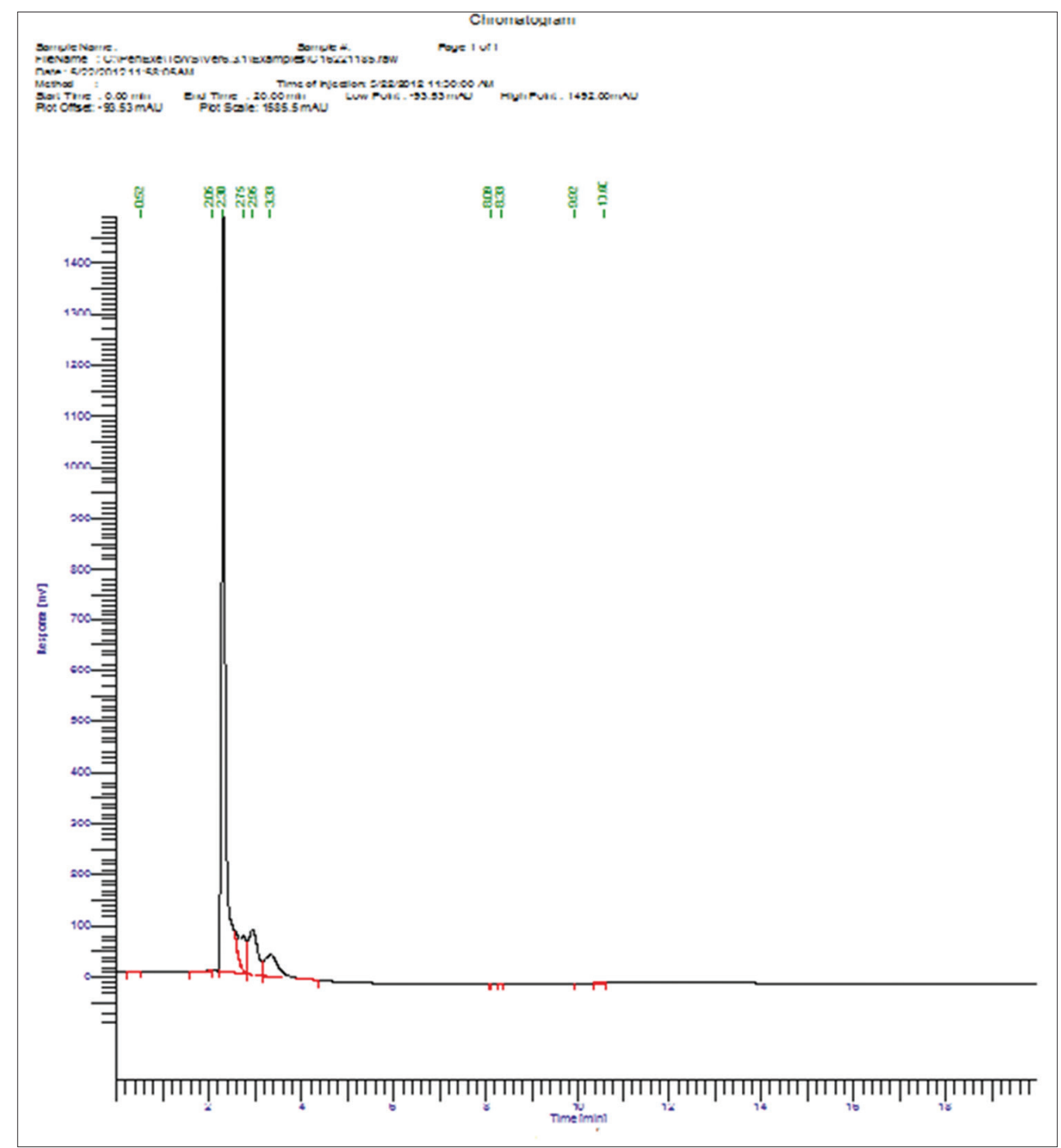

Fig. 1: Analytical high-performance liquid chromatography of isolated fraction Pajanelia fraction-3

( $0.24 \pm 0.01$ unit/mg protein), GPx $(26.68 \pm 1.01$ unit $/ \mathrm{mg}$ protein $)$, and GSH (14.34 \pm 0.31 unit/mg protein) values over those of the control group LPO $(0.66 \pm 0.01$ nmoles thiobarbituric acid reactive substances (TBARS) $/ \mathrm{mg}$ protein) and SOD, CAT, GPx and GSH $(1.92 \pm 0.00,0.78 \pm 0.02,87.36 \pm 1.12$ and $64.87 \pm 1.51$ unit/mg protein, respectively). Pretreatment with fraction F1, $\mathrm{F} 2$ and $\mathrm{F} 3$ at a concentration of $150 \mathrm{mg} / \mathrm{kg}$ b.w. p.o. conferred significant $(\mathrm{p}<0.001$ and $\mathrm{p}<0.01$ compared to control, $\mathrm{p}<0.001$ compared to toxic and $\mathrm{p}<0.01$ compared to standard) antioxidant activity in enzymatic and nonenzymatic levels in Swiss albino mice by lowering the elevated levels of LPO and by increasing the decreased levels of SOD, CAT, GPx, and GSH. Fraction PF3 exhibited a maximum level ( $\mathrm{p}<0.001$ compared to toxic) of antioxidant activity, LPO $(0.96 \pm 0.02$ nmoles TBARS $/ \mathrm{mg}$ protein $)$ and SOD, CAT, GPx and GSH $(0.92 \pm 0.01,0.49 \pm 0.02,42.84 \pm 2.70$ and $47.73 \pm 1.44$ unit/mg protein, respectively) and $300 \mathrm{mg} / \mathrm{kg}$ b.w. p.o. dose exhibited least level ( $\mathrm{p}<0.001$ compared to toxic, standard and control, respectively) of antioxidant activity. Silymarin $(50 \mathrm{mg} / \mathrm{kg}$ b.w. p.o.) also significantly altered the levels of LPO $(0.76 \pm 0.02$ nmoles TBARS/mg protein), SOD (1.84 \pm 0.01 unit/mg protein), CAT $(0.71+5 \pm 0.01 \mathrm{unit} / \mathrm{mg}$ protein $), \mathrm{GPx}(68.73 \pm 1.96 \mathrm{unit} / \mathrm{mg}$ protein $)$, and GSH (66.76 \pm 0.87 unit/mg protein) as compared with the $\mathrm{CCl}_{4}$ group (Table 2).
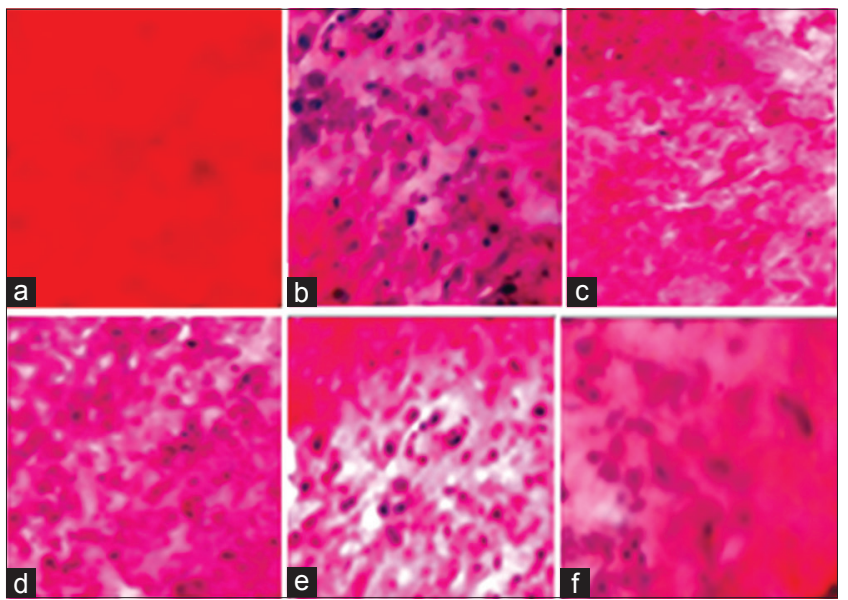

Fig. 2: Sections stained with hematoxylin and eosin and observed under microscope (BX41, OLYMPUS) displaying the liver sections of mice treated with. (a) Control, (b) carbon tetrachloride $(0.5 \mathrm{ml} / \mathrm{kg}$ body weight [b.w.] intraperitoneal), (c) Silymarin $(50 \mathrm{mg} / \mathrm{kg} \mathrm{b.w.} \mathrm{per}$ orally [p.o.]), (d) $150 \mathrm{mg} / \mathrm{kg}$ b.w. p.o. dose of Pajanelia fraction-1 (PF1), (e) $150 \mathrm{mg} / \mathrm{kg}$ b.w. p.o. dose of PF2 (f) $150 \mathrm{mg} / \mathrm{kg}$ b.w. p.o. dose of PF3 
Table 2: Antioxidant efficacy of isolated fractions on tissue enzymatic and nonenzymatic levels of Swiss albino mice against $\mathrm{CCl}_{4}$ induced hepatic damage

\begin{tabular}{|c|c|c|c|c|c|}
\hline Doses & $\begin{array}{l}\text { LPO } \\
\text { (nmoles TBARS/mg protein) }\end{array}$ & $\begin{array}{l}\text { GSH } \\
\text { (unit/mg protein) }\end{array}$ & $\begin{array}{l}\text { CAT } \\
\text { (unit/mg protein) }\end{array}$ & $\begin{array}{l}\text { SOD } \\
\text { (unit/mg protein) }\end{array}$ & $\begin{array}{l}\text { GPx } \\
\text { (unit/mg protein) }\end{array}$ \\
\hline Group I & $0.66 \pm 0.01$ & $64.87 \pm 1.51$ & $0.78 \pm 0.02$ & $1.92 \pm 0.00$ & $87.36 \pm 1.12$ \\
\hline Group II & $5.19 \pm 0.03^{\mathrm{a}}$ & $14.34 \pm 0.31^{\mathrm{a}}$ & $0.24 \pm 0.01^{\mathrm{a}}$ & $0.72 \pm 0.01^{\mathrm{a}}$ & $26.68 \pm 1.01^{\mathrm{a}}$ \\
\hline Group III & $1.43 \pm 0.02^{\mathrm{a}, \mathrm{e}}$ & $51.03 \pm 1.91^{\mathrm{b}, \mathrm{e}}$ & $0.72 \pm 0.01^{\mathrm{e}}$ & $1.39 \pm 0.01^{\mathrm{a}, \mathrm{e}}$ & $68.30 \pm 1.71^{\mathrm{a}, \mathrm{e}}$ \\
\hline Group IV & $2.86 \pm 0.03^{\mathrm{a}, \mathrm{e}}$ & $57.73 \pm 1.24^{\mathrm{b}, \mathrm{e}}$ & $0.63 \pm 0.02^{\mathrm{e}}$ & $0.87 \pm 0.01^{\mathrm{a}, \mathrm{e}}$ & $92.14 \pm 1.36^{\mathrm{b}, \mathrm{e}}$ \\
\hline Group V & $1.18 \pm 0.01^{\mathrm{a}, \mathrm{e}}$ & $62.17 \pm 1.42^{\mathrm{a}, \mathrm{e}}$ & $0.69 \pm 0.01^{\mathrm{b}, \mathrm{e}}$ & $1.87 \pm 0.01^{\mathrm{a}, \mathrm{e}}$ & $83.86 \pm 0.90^{\mathrm{a}, \mathrm{e}}$ \\
\hline Group VI & $0.76 \pm 0.02^{\mathrm{a}, \mathrm{d}, \mathrm{e}}$ & $66.76 \pm 0.87^{\mathrm{a}, \mathrm{f}, \mathrm{e}}$ & $0.71 \pm 0.01^{\mathrm{a}, \mathrm{e}}$ & $1.84 \pm 0.01^{\mathrm{a}, \mathrm{e}, \mathrm{f}}$ & $68.73 \pm 1.96^{\mathrm{a}, \mathrm{e}, \mathrm{g}}$ \\
\hline
\end{tabular}

$\mathrm{n}=6$ animal, values are given as mean $\pm \mathrm{SE}$, values are statistically significant at $\mathrm{p}<0.001, \mathrm{p}<0.01$ and $\mathrm{p}<0.05$ level of significance. ${ }^{\mathrm{a} C o m p a r e d}$ with control $\mathrm{p}<0.001$, ${ }^{\mathrm{b} C}$ Compared with control $\mathrm{p}<0.01$, ${ }^{\mathrm{c} C o m p a r e d}$ with control $\mathrm{p}<0.05$, ${ }_{\mathrm{d}}^{\mathrm{d}} \mathrm{Compared}$ with standard $\mathrm{p}<0.001$, ${ }^{\mathrm{e}}$ Compared with toxic $\mathrm{p}<0.001$, $\mathrm{f}$ Compared with standard $\mathrm{p}<0.01,{ }^{\mathrm{g}}$ Compared with standard p $<0.001$. Group I -Control, Group II - Toxic ( $\mathrm{CCl}_{4}$ ), Group III - Standard (Silymarin), Group IV - $150 \mathrm{mg} / \mathrm{kg}$ b.w. p.o. dose of PF1; Group V - 150 mg/kg b.w. p.o. dose of PF2; Group VI - 150 mg/kg b.w. p.o. dose of PF3. LPO: Lipid peroxidation, GSH: Reduced glutathione, CAT: Catalase, SOD: Superoxide dismutase, GPx: Glutathione peroxidase, SE: Standard error, $\mathrm{CCl}_{4}$ : Carbon tetrachloride, PF: Pajanelia fraction, TBARS: Thiobarbituric acid reactive substances

\section{Histopathology of liver}

The protective efficacy of fractions was further analyzed by histopathological study where it was found that $150 \mathrm{mg} / \mathrm{kg}$ b.w. p.o. dose of PF3 exhibited a maximum level of healing of necrosis which was nearly similar to the control group (Fig. 2) where normal hepatocytes were found.

\section{DISCUSSION}

The hepatic cells consist of higher concentration of GOT and GPT in cytoplasm and GOT particularly exists in mitochondria. Due to the necrosis or membrane damage the hepatospecific enzymes are released in circulation, and therefore, it can be measured by measuring the serum enzyme levels. High concentration of bilirubin in the serum is an indication for increased erythrocyte degeneration rate. On the other hand, ALP level in serum is related to the function of hepatic cells. Increased ALP level in serum is due to increase its synthesis in presence of increasing biliary pressure. Mammalian cells contain antioxidant enzymes, including CAT, SOD, and GPx. For the maintenance of the bodies redox balance the body cells tightly maintained the levels of these enzymes and also non-enzymes such as LPO and GSH [21]. Free radicals are detoxified by antioxidant enzymes and are converted to more stable molecules. The activity of CAT enzyme results in the conversion of hydrogen peroxide to water and oxygen.

Melondialdehyde is a breakdown product of LPO, and therefore, it is a useful index of LPO. In another case, water and oxidized glutathione were produced by the combined activity of GSH and hydrogen peroxide, where GPx helps to this conjugation [22]. A significant increase in serum enzymes and bilirubin levels and a significant decrease in antioxidant enzymatic and nonenzymatic levels were recorded after $5^{\text {th }}$ day of $\mathrm{CCl}_{4}$ intoxication, indicating considerable hepatocellular injury. Isolated fractions PF1, PF2 and PF3 from bark of the selected plant were exhibited significant activity in a used dose dependent manner. The fractions were subsequently recovered the serum enzymes, bilirubin and antioxidant enzymatic and nonenzymatic levels toward normal condition. PF3 from P. longifolia (Willd.) K. Schuman exhibited maximum level of liver protective as well as antioxidant activity at a dose of $150 \mathrm{mg} / \mathrm{kg}$ b.w. which was similar and in some cases better than standard drug Silymarin ( $50 \mathrm{mg} / \mathrm{kg}$ b.w.). From this study, it is evident that the fraction PF3 has drug curricular activity. Fraction PF3 has showed better protective activity compare to standard drug silymarin. Hence, fraction PF3 can be considered for further studies.

\section{CONCLUSION}

PF3 from ethyl acetate extract of $P$. longifolia (Willd.) K. Schuman can be considered as an effective liver protective as well as oxidative stress reducing agent as it ameliorates almost to normalcy the damage caused by $\mathrm{CCl}_{4}$ to hepatic function.

\section{ACKNOWLEDGMENT}

The authors are grateful to the University Grant Commission for providing financial assistance in the form of UGC-AUS fellowship. Authors are thankful to Dr. Shuvasish Choudhury, CIL Assam University for necessary help and guide. Furthermore, authors are thankful to Bioinformatics Centre, Assam University for e-journal access facilities.

\section{REFERENCES}

1. Cesaratto L, Vascotto C, Calligaris $\mathrm{S}$, Tell G. The importance of redox state in liver damage. Ann Hepatol 2004;3(3):86-92.

2. Meenakshi J, Madhuri M, Maya A, Hemant S. Synthesis, free radical scavenging and DNA cleavage activities of some novel indole derivatives. Int J Pharm Pharm Sci 2015;7(7):97-103.

3. Archana D, Dixitha M, Santhy KS. Antioxidant and anti clastogenic potential of Piper longum L. Int J Appl Pharm 2015;7(2):11-4.

4. Ajay K, Monika S, Prem PS, Sandeep KS, Pratima R, Kapil DP. Antioxidant efficacy and curcumin content of turmeric (Curcuma-longa L.) Flower. Int J Curr Pharm Res 2016; 8(3):112-4.

5. Yadav NP, Dixit VK. Hepatoprotective activity of leaves of Kalanchoe pinnata Pers. J Ethnopharmacol 2003;86:197-202.

6. Margret RE, Murugan N, Praveen KP, Nimal CI. In vitro studies on a-glucosidase inhibition, antioxidant and free radical scavenging properties of Tecoma stans L. Int J Pharm Pharm Sci 2015;7(6):44-9.

7. Chatterjee TK. Medicinal Plants with Hepatoprotective Properties in Herbal Opinions. Vol. III. Calcutta: Books and Allied (P) Ltd.; 2000. p. 135.

8. Chattopadhyay RR. Possible mechanism of hepatoprotective activity of Azadirachta indica leaf extract: Part II. J Ethnopharmacol 2003;89(2-3):217-9.

9. Bhandarkar MR, Khan A. Antihepatotoxic effect of Nymphaea stellata willd. Against carbon tetrachloride-induced hepatic damage in albino rats. J Ethnopharmacol 2004;91(1):61-4.

10. Datta S, Choudhury S, Choudhury MD. Hepatoprotective activity of bark of Pajanelia longifolia (Willd.) K. Schumann against $\mathrm{CCl}_{4}$ induced hepatic damage in mice. Drug Invent Today 2012; 4(10):537-9.

11. Siddiqui A, Ali A. Practical Pharmaceutical Chemistry. $1^{\text {st }}$ ed. New Delhi, India: CSD Publishers; 1997. p. 125-31.

12. Ozbek H, Ugras S, Bayram I, Urgan I, Erdogan E. Hepatoprotective effect of Foeniculum vulgare essential oil. Acarbon tetrachloride induced liver fibrosis model of rats. Scand J Lab Anim Sci 2004;31(1):9-17.

13. Reitman S, Frankel S. A colorimetric method for the determination of serum glutamic oxalacetic and glutamic pyruvic transaminases. Am J Clin Pathol 1957;28(1):56-63.

14. Malloy HR, Evelyn KA. The determination of bilirubin with the photoelectric colorimeter. J Biol Chem 1937;119(2):481.

15. Sood R. Medical Laboratory Technology, Methods and Interpretation. $5^{\text {th }}$ ed. New Delhi: Jaypee Brothers Medical Publishers Ltd.; 1999. p. 488-90.

16. Mohandas J, Marshal J, Duggin G, Horvath JS, Tiller D. Differential distribution of glutathione and glutathione related enzymes in rabbit kidney. Cancer Res 1984;44(11):5086-91.

17. Pedraza-Chaverri J, Barrera D, Medina-Campos ON, Carvajal RC, Fernandez-Pando R, Macias-RovalCaba NA. Time course study of 
oxidative andnitrosative stress and antioxidant enzymes in $\mathrm{K}_{2} \mathrm{Cr}_{2} \mathrm{O}_{7}$ inducad hepatotoxicity. BMC Nephrol 2005;6:4.

18. Dhindsa RH, Dhindsa P, Thorpe TA. Leaf Senescence correlated with increased level of membrane permeability, lipid peroxidation and decreased level of SOD and CAT. J Exp Bot 1981;32:93-101.

19. Ellman GL. Tissue sulphydryl groups. Arch Biochem Biophys 1959;82(1):70-7

20. Mihara M, Uchiyama M. Determination of malonaldehyde precursor in tissues by thiobarbituric acid test. Anal Biochem 1978;86(1):271-8.

21. Saeed SA, Urfy MZ, Ali TM, Khimani FW, Gilani A. Antioxidants: Their role in health and disease. Int J Pharm 2005;1(3):226-33.

22. Akindele AJ, Ezenwanebe KO, Anunobi CC, Adeyemi OO. Hepatoprotective and in vivo antioxidant effects of Byrsocarpus coccineus Schum. and Thonn. (Connaraceae). J Ethnopharmacol 2010;129(1):46-52. 